\title{
Prognostic significance of epidermal growth factor receptor (EGFR) over expression in urothelial carcinoma of urinary bladder
}

\author{
Atif Ali hashmi ', Zubaida Fida Hussain ${ }^{1}$, Muhammad Irfan ${ }^{1}$, Erum Yousuf Khan ${ }^{1}$, Naveen Faridi ${ }^{1}$, Hanna Naqvi,
} Amir Khan ${ }^{3^{*}}$ and Muhammad Muzzammil Edhi

\begin{abstract}
Background: Epidermal growth factor receptor (EGFR) has been shown to have abnormal expression in many human cancers and is considered as a marker of poor prognosis. Frequency of over expression in bladder cancer has not been studied in our population; therefore we aimed to evaluate the frequency and prognostic significance of EGFR immunohistochemical expression in locoregional population.

Methods: We performed EGFR immunohistochemistry on 126 cases of bladder cancer and association of EGFR expression with tumor grade, lamina propria invasion, deep muscle invasion and recurrence of disease was evaluated.

Results: High EGFR expression was noted in 26.2\% (33 cases), 15.1\% (19 cases) and 58.7\% (74 cases) revealed low and no EGFR expression respectively. Significant association of EGFR expression was noted with tumor grade, lamina propria invasion, deep muscle invasion and recurrence status while no significant association was seen with age, gender and overall survival. Kaplan- Meier curves revealed significant association of EGFR expression with recurrence while no significant association was seen with overall survival.
\end{abstract}

Conclusion: Significant association of EGFR overexpression with tumor grade, muscularis propria invasion and recurrence signifies its prognostic value; therefore EGFR can be used as a prognostic biomarker in Urothelial bladder carcinoma.

Keywords: Bladder cancer, Muscle invasion, Epidermal growth factor receptor, EGFR, Urothelial carcinoma

\section{Background}

Bladder cancer is the fifth commonest malignancy in males all over the world [1]. Most of the bladder tumors have transitional cell (urothelial) morphology and they have a natural propensity to progress from superficial non-invasive tumors to deep muscle invasive cancers [2] . Prognosis of bladder cancer depends upon grade and stage of the disease. The single most important factor for determining disease prognosis in bladder cancer is muscle invasion; the presence of which makes therapeutic approach more radical. The only therapeutic option for muscle invasive bladder cancer is radical cystectomy or radical radiotherapy; however 5 year survival remains poor
$[3,4]$. On the other hand, non-muscle invasive tumors can recur and progress with time to muscle invasive disease [5]. Therefore detection of abnormal expression of biological markers is under intense scrutiny in bladder cancer, which can serve as prognostic or predictive factors in bladder cancers. Epidermal growth factor receptor (EGFR) has been shown to have abnormal expression in many human cancers and is considered as a marker of poor prognosis [6]. Frequency of over expression in bladder cancer has not been studied in our population; therefore we aimed to evaluate the frequency and prognostic significance of EGFR immunohistochemical expression in locoregional population.

* Correspondence: dramirkhan04@gmail.com

${ }^{3}$ Kandahar University, Kandahar, Afghanistan

Full list of author information is available at the end of the article

(c) The Author(s). 2018 Open Access This article is distributed under the terms of the Creative Commons Attribution 4.0 International License (http://creativecommons.org/licenses/by/4.0/), which permits unrestricted use, distribution, and reproduction in any medium, provided you give appropriate credit to the original author(s) and the source, provide a link to the Creative Commons license, and indicate if changes were made. The Creative Commons Public Domain Dedication waiver (http://creativecommons.org/publicdomain/zero/1.0/) applies to the data made available in this article, unless otherwise stated. 


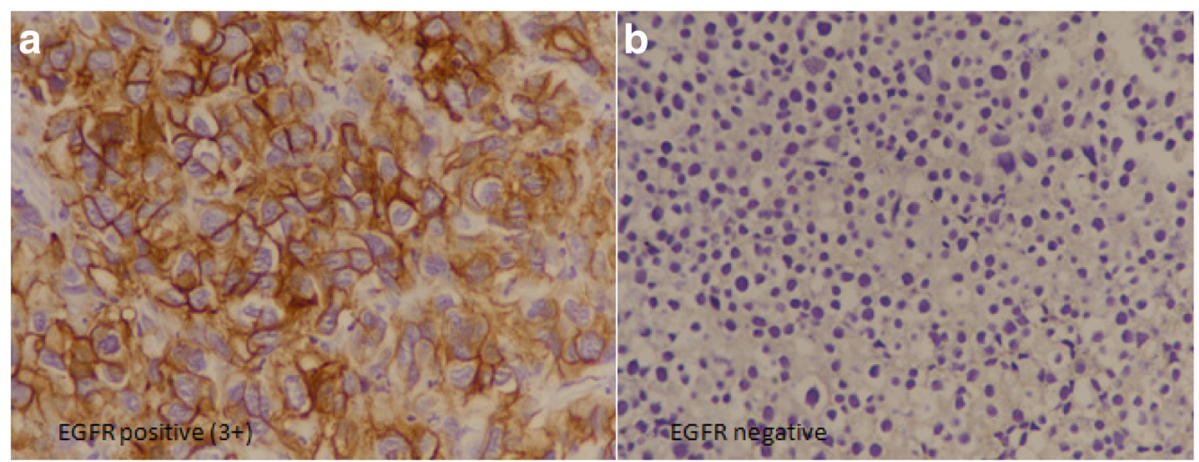

Fig. 1 Positive (Strong \& diffuse) and negative EGFR expression in bladder cancer (400x magnification)

\section{Methods}

\section{Selection of cases}

Total 126 diagnosed cases of urothelial carcinoma specimens of urinary bladder were selected from records of pathology department. Cases of bladder cancer which were diagnosed other than urothelial carcinomas were excluded. All patients underwent surgeries at Liaquat National hospital, Karachi from January 2010 till December 2014 over a period of 5 years. The study was approved by research and ethical review committee of Liaquat National Hospital and informed written consent was taken from all patients at the time of surgery. Hematoxylin and eosin stained slides and paraffin blocks of all cases were retrieved and new sections were cut where necessary. Slides of all cases were reviewed by two senior histopathologists and pathologic characteristics like tumor grade, lamina propria invasion, muscularis propria invasion were evaluated. Deep muscle invasion was analyzed when thick muscle bundles of muscularis propria were present in transurethral resection specimen. Clinical records of 58 patients were available and are thus reviewed from institutional records to evaluate recurrence and survival status. Moreover, representative tissue blocks of each case were selected for EGFR immunohistochemistry.

\section{Immunohistochemistry}

EGFR immunohistochemistry was performed using using DAKO Monoclonal Mouse Anti-human Epidermal growth factor Receptor (EGFR), clone H11. 1:100 dilution was done using phosphate buffer saline (incubation time $30 \mathrm{mins}$ at room temperature). To reduce background, incubation was done at room temperature for 20 min using proteinase $\mathrm{K}$ solution. Detection method was DAKO EnVision method, DAB was used as chromogen substrate (incubation time 1-3 min at room temperature) and counter stain was hematoxylin. Skin tissue was used as control. Both membranous and cytoplasmic staining for EGFR was both quantitatively and qualitatively evaluated. Intensity of staining was categorized into no staining $(0)$, weak $(1+)$, intermediate $(2+)$, strong $(3+)$ while percentage of positively stained cells were measured as continuous variable. The following scoring approach in the assessment of EGFR immunostaining was used: score $0=$ no staining, unspecific staining of tumor cells or less than $10 \%$ staining, score 1

Table 1 Demographic profile of patients involved in the study

\begin{tabular}{|c|c|}
\hline & n (\%) \\
\hline Age (years) ${ }^{a}$ & $63.61 \pm 14.49$ \\
\hline Follow up (months) $)^{a, b}$ & $22.76 \pm 13.66$ \\
\hline EFGR (\%) ${ }^{a}$ & $14.50 \pm 22.41$ \\
\hline \multicolumn{2}{|l|}{ Gender } \\
\hline Male & $91(72.2)$ \\
\hline Female & $35(27.8)$ \\
\hline \multicolumn{2}{|l|}{ Specimen Type } \\
\hline Transurethral resection & 121(96) \\
\hline Radical Cystectomy & $5(4)$ \\
\hline \multicolumn{2}{|l|}{ Tumor Grade } \\
\hline Low Grade Papillary Urothelial Carcinoma & $65(51.6)$ \\
\hline High Grade Papillary Urothelial Carcinoma & $61(48.4)$ \\
\hline \multicolumn{2}{|l|}{ Lamina Propria Invasion } \\
\hline Present & $35(27.8)$ \\
\hline Absent & $91(72.2)$ \\
\hline \multicolumn{2}{|l|}{ Deep Muscle Invasion } \\
\hline Present & $22(17.5)$ \\
\hline Absent & $59(46.8)$ \\
\hline Can't Assessed & $45(35.7)$ \\
\hline \multicolumn{2}{|l|}{ Recurrence $(n=58)$} \\
\hline Yes & $25(43.1)$ \\
\hline No & $33(56.9)$ \\
\hline \multicolumn{2}{|l|}{ Survival Status $(n=58)$} \\
\hline Alive & $49(84.5)$ \\
\hline Expired & $9(15.5)$ \\
\hline
\end{tabular}

${ }^{\mathrm{a} M e a n} \pm \mathrm{SD}$

${ }^{b} 58$ cases 
$=$ membranous weak and incomplete staining of more than $10 \%$ of tumor cells, score $2=$ moderate and complete membranous staining of more than $10 \%$ of tumor cells, score $3=$ strong and complete membranous staining of more than $10 \%$ of tumor cells. Scored1+ tumors were classified as Low EGFR expression and those scored $2+$ or $3+$ were classified as High EGFR expression $^{18}$ (Fig. 1).

\section{Follow-up and recurrence}

Recurrence status and follow-up were evaluated by reviewing hospital medical records. Overall survival was taken as time from surgical excision till death or last follow-up and disease free survival was defined as time between surgical excision and local recurrence or distant metastasis, death or last follow-up.

\section{Statistical analysis}

Statistical package for social sciences (SPSS 21) was used for data compilation and analysis. Mean and standard deviation were calculated for quantitative variables. Frequency and percentage were calculated for qualitative variables. Chi-square was applied to determine association. Student t test or Mann witney test were applied to compare difference in means among groups. $P$-value $\leq 0.05$ as significant. Survival curves were plotted using Kaplan- Meier method and the significance of difference between survival curves were determined using log-rank ratio. $P$-value $\leq 0.05$ was taken as significant.

\section{Results}

Mean age of patients was $63.61 \pm 14.49$ years with male to female ratio of 2.6:1. 96\% specimens were of transurethral resections. $48.4 \%$ (61 cases) were of high grade morphology,

Table 2 Association of EGFR Expression with clinicopathologic features of Urothelial carcinoma

\begin{tabular}{|c|c|c|c|c|c|}
\hline & \multicolumn{4}{|l|}{ EFGR Expression $n(\%)$} & \multirow[t]{2}{*}{ P-Value } \\
\hline & No Expression $(n=74)$ & Low EFGR Expression $(n=19)$ & High EFGR expression $(n=33)$ & Total $(n=126)$ & \\
\hline \multicolumn{6}{|l|}{ Gender } \\
\hline Male & $54(73)$ & 14(73.7) & $23(69.7)$ & $91(72.2)$ & \multirow[t]{2}{*}{0.930} \\
\hline Female & $20(27)$ & $5(26.3)$ & 10(30.3) & $35(27.8)$ & \\
\hline \multicolumn{6}{|l|}{ Age Group ${ }^{a}$} \\
\hline$\leq 25$ years & $1(1.4)$ & $0(0)$ & $0(0)$ & $0(0)$ & \multirow[t]{3}{*}{0.263} \\
\hline $26-50$ years & $21(28.4)$ & $2(10.5)$ & $2(10.5)$ & $5(15.2)$ & \\
\hline$>50$ years & $52(70.3)$ & $17(89.5)$ & $17(89.5)$ & $28(84.8)$ & \\
\hline \multicolumn{6}{|l|}{ Specimen Type ${ }^{a}$} \\
\hline Transurethral resection & 72(97.3) & 19(100) & 30(90.9) & $121(96)$ & \multirow[t]{2}{*}{0.209} \\
\hline Radical Cystectomy & $2(2.7)$ & $0(0)$ & $3(9.1)$ & $5(4)$ & \\
\hline \multicolumn{6}{|l|}{ Tumor Grade } \\
\hline Low Grade & $48(64.9)$ & $9(47.4)$ & $8(24.2)$ & $65(51.6)$ & \multirow[t]{2}{*}{0.000} \\
\hline High Grade & $26(35.1)$ & $10(52.6)$ & 25(75.8) & $61(48.4)$ & \\
\hline \multicolumn{6}{|l|}{ Lamina Propria Invasion } \\
\hline Present & $15(20.3)$ & $3(15.8)$ & $17(51.5)$ & $35(27.8)$ & \multirow[t]{2}{*}{0.002} \\
\hline Absent & $59(79.7)$ & $16(84.2)$ & $16(48.5)$ & $91(72.2)$ & \\
\hline \multicolumn{6}{|l|}{ Deep Muscle Invasion ${ }^{a}$} \\
\hline Present & $9(12.2)$ & $1(5.3)$ & $12(36.4)$ & $22(17.5)$ & \multirow[t]{3}{*}{0.012} \\
\hline Absent & $38(51.4)$ & $12(63.2)$ & $9(27.3)$ & $59(46.8)$ & \\
\hline Can't Assessed & $27(36.5)$ & $6(31.6)$ & $12(36.4)$ & $45(35.7)$ & \\
\hline \multicolumn{6}{|l|}{ Recurrence $(n=58)^{\text {a }}$} \\
\hline Yes & $15(40.5)$ & $0(0)$ & $10(66.7)$ & $25(43.1)$ & \multirow[t]{2}{*}{0.017} \\
\hline No & $22(59.5)$ & $6(100)$ & $5(33.3)$ & $33(56.9)$ & \\
\hline \multicolumn{6}{|l|}{ Survival Status $(n=58)^{a}$} \\
\hline Alive & $32(86.5)$ & $6(100)$ & $11(73.3)$ & $49(84.5)$ & \multirow[t]{2}{*}{0.398} \\
\hline Expired & $5(13.5)$ & $0(0)$ & $4(26.7)$ & $9(15.5)$ & \\
\hline
\end{tabular}

Chi-Square test applied

${ }^{\text {a}}$ Fisher Exact test applied

$P$-Value $\leq 0.05$, considerd as significant 
whereas 51.6\% (65 cases) showed low grade histology. Lamina propria invasion was seen in $27.8 \%$ (35 cases), while muscularis propria invasion was noted in $17.5 \%$ (22 cases). Mean follow up of patients involved in the study was 22.76 \pm 13.66 months and recurrence was seen in $43.1 \%$ (25 cases) as presented in Table 1. However, in 45 cases (35.7\%) deep muscle was not present in the specimen and therefore deep muscle invasion couldn't be assessed.

According to scoring system used; high EGFR expression was noted in $26.2 \%$ (33 cases), $15.1 \%$ (19 cases) and 58.7\% (74 cases) revealed low and no EGFR expression respectively.

Significant association of EGFR expression was noted with tumor grade, lamina propria invasion, deep muscle invasion and recurrence status while no significant association was seen with age, gender and overall survival (Table 2). Kaplan- Meier curves revealed significant association of EGFR expression with recurrence while no significant association was seen with overall survival (Figs. 2 and 3).

\section{Discussion}

In the current study, we evaluated EGFR expression in bladder cancers of locoregional population and found EGFR expression in 46\% cases of bladder cancer. Moreover, we found a significant association of EGFR expression with prognostic parameters like grade, lamina propria, deep muscle invasion and recurrence.

EGFR belongs to tyrosine kinase receptor family, all of which are encoded by c-erbB oncogenes. EGFR is the product of c-erbB1 proto-oncogene, which serves as a receptor for several growth factors like epidermal growth factor, transforming growth factor alpha, amphiregulin, heparin binding EGF like factor, betacellulin and epiregulin [7]. Activation of EGFR by one of its ligands leads to intracellular cascade of events resulting in transcriptional activation and cell proliferation $[8,9]$. EGFR over expression occurs in many epithelial and solid malignancies like lung, breast and colon cancer. Several studies reported over expression of EGFR in bladder cancer. Results of most of the literature revealed that more than half of cases of bladder cancer overexpresses EGFR [10, 11]. Our data is in accordance with the reported literature; as we found significant association of EGFR expression with tumor grade, lamina propria and muscularis propria invasion; which are among most important prognostic factors in bladder cancer. Moreover, high frequency of recurrence was noted in patients with tumor showing intermediate and strong EGFR expression. Literature review revealed association of EGFR expression with high tumor grade, stage, tumor progression and poor clinical outcome

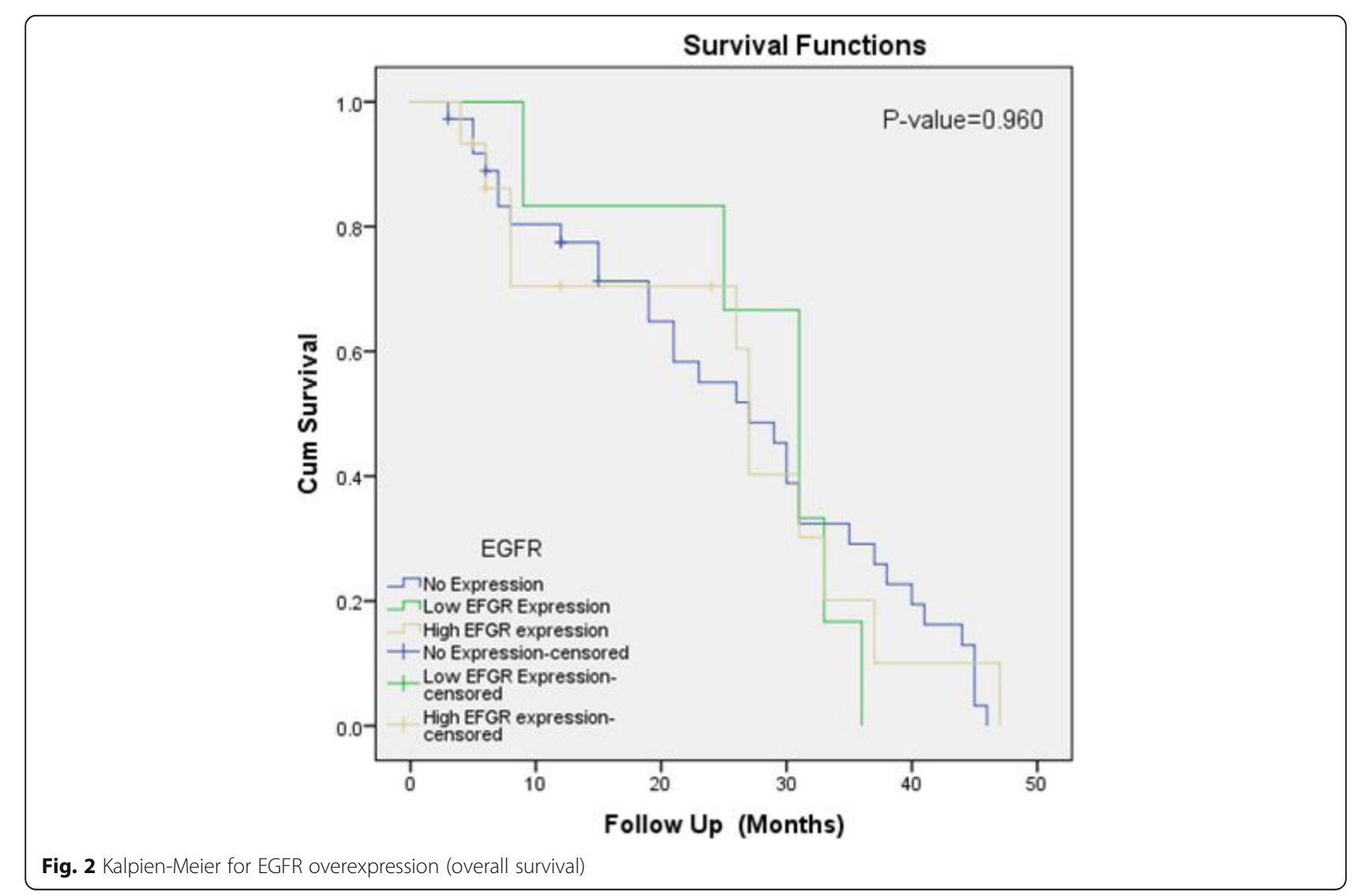




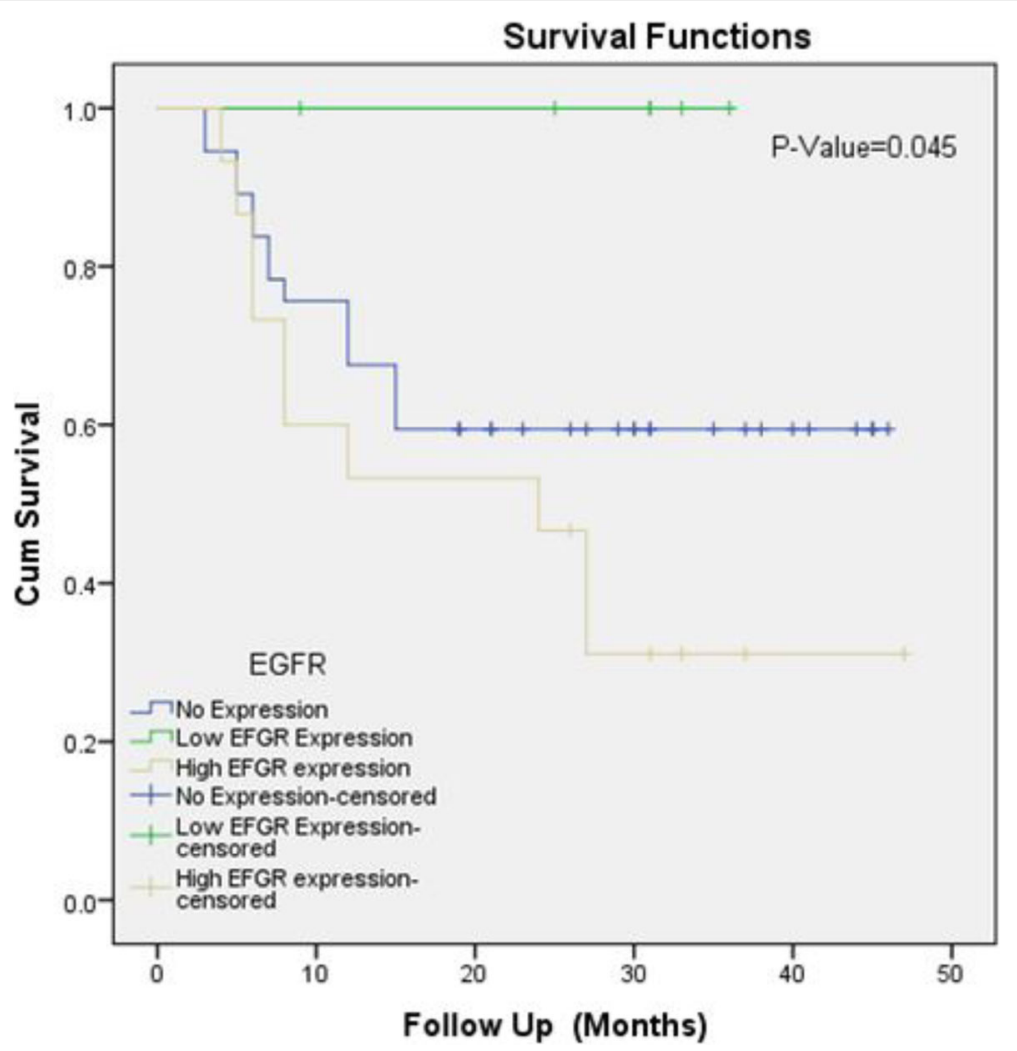

Fig. 3 Kalpien-Meier for EGFR overexpression (recurrence)

[6, 12, 13]. Carisson J et al., reported 71\% EGFR expression in primary bladder tumors and co-expression of EGFR and Her2neu (c-erbB2) in more than half of patients [14]. Badaway AA et al., found EGFR expression in $86 \%$ cases of bladder cancer. They reported significant association of EGFR expression with grade and tumor stage [15]. Similarly, Arfaoni AT et al., reported statistically significant correlation of EGFR expression with tumor grade and stage [16].The mechanism of EGFR over expression resulting poor prognosis is still unclear. However, evidence suggests that activation of EGFR leads to activation of activator protein of transcription factor which results in induction of matrix metalloproteinases activity [17].

\section{Conclusion}

Significant association of EGFR overexpression with tumor grade, muscularis propria invasion and recurrence signifies its prognostic value; therefore EGFR can be used as a prognostic biomarker in Urothelial bladder carcinoma.

\section{Abbreviation}

EGFR: Epidermal growth factor receptor

\section{Acknowledgments}

We gratefully acknowledge all staff members of Pathology, Liaquat National Hospital, Karachi, Pakistan for their help and cooperation.

\section{Availability of data and materials}

Please contact author, Atif Ali Hashmi (doc_atif2005@yahoo.com) for data requests.

\section{Authors' contributions}

$\mathrm{AAH}$ and ZFH: main author of manuscript, have made substantial contributions to conception and design of study. MI, EYK and NF: been involved in drafting the manuscript, revising it critically for important intellectual content, and have been involved in requisition of data. HN, AK and MME have been involved in analysis of the data and revision of the manuscript. All authors read, revise and gave approval of the manuscript.

\section{Ethics approval and consent to participate}

Ethics committee of Liaquat National Hospital, Karachi, Pakistan approved the study. Written informed consent was obtained from the patients for the participation analysis of data.

\section{Competing interests}

The authors declare that they have no competing interests.

\section{Publisher's Note}

Springer Nature remains neutral with regard to jurisdictional claims in published maps and institutional affiliations.

\section{Author details}

${ }^{1}$ Liaquat National Hospital and Medical College, Karachi, Pakistan. ${ }^{2}$ Brown University, Providence, RI, USA. ${ }^{3}$ Kandahar University, Kandahar, Afghanistan. 
Received: 15 January 2018 Accepted: 31 May 2018

Published online: 07 June 2018

\section{References}

1. Office of National Statistics. StatBase: cancer: incidence rates per 100,000 population 1998 by age and sex. London: ONS.

2. Lutzeyer W, Rubben H, Dahm H. Prognostic parameters in superficial bladder cancer: an analysis of 315 cases. J Urol. 1982;127:250-2.

3. Pearse HD, Reed RR, Hodges CV. Radical cystectomy for bladder cancer. J Urol. 1978;119:216-8.

4. Skinner DG, Lieskovsky G. Contemporary cystectomy with pelvic node dissection compared to preoperative radiation therapy plus cystectomy in the management of invasive bladder cancer. J Urol. 1984;131:1069-72.

5. Fitzpatrick JM, West AB, Butler MR, et al. Superficial bladder tumours (stages pTa, grade 1 and 2): the importance of recurrence pattern following initial resection. J Urol. 1986;135:920-2.

6. Neal DE, Sharples L, Smith K, et al. The epidermal growth factor receptor and the prognosis of bladder cancer. Cancer. 1990;65:1619-25.

7. Kondo I, Shimizu N. Mapping of the human gene for epidermal growth actor receptor (EGFR) on the p13 leads to q22 region of chromosome 7 . Cytogenet Cell Genet. 1983;35:9-14.

8. Gullick WJ. Prevalence of aberrant expression of the epidermal growth factor receptor in human cancers. Br Med Bull. 1991;47:87-98.

9. Carpernter G, Cohen S. Epidermal growth factor receptor. J Biol Chem. 1990;265:7709-12.

10. Nicholson RI, Gee JMW, Harper MEEGFR. cancer prognosis. Eur J Cancer. 2001;37:S9-15

11. Neal DE, Marsh C, Bennett MK, et al. Epidermal growth factor receptors in human bladder cancer: comparison of invasive and superficial tumours. Lancet 1985; i:366-368.

12. Nguyen PL, Swanson PE, Jaszcz W, et al. Expression of epidermal growth factor receptor in invasive transitional cell carcinoma of the urinary bladder: a multivariate survival analysis. Am J Clin Pathol. 1994;101:166-76.

13. Mellon JK, Wright C, Kelly P, et al. Long-term outcome related to EGFR status in bladder cancer. J Urol. 1995:153:919-25.

14. Carlsson J, Wester K, De La Torre M, Malmström PU, Gårdmark T. EGFRexpression in primary urinary bladder cancer and corresponding metastases and the relation to HER2-expression. On the possibility to target these receptors with radionuclides. Radiol Oncol. 2015 Mar 3:49(1):50-8.

15. Badawy AA, El-Hindawi A, Hammam O, Moussa M, Helal NS, Kamel A. Expression of epidermal growth factor receptor and transforming growth factor alpha in Cancer bladder: Schistosomal and non-Schistosomal. Curr Urol. 2017 Jan;9(4):192-201.

16. Arfaoui AT, Mejri S, Belhaj R, Karkni W, Chebil M, Rammeh S. Prognostic value of immunohistochemical expression profile of epidermal growth factor receptor in urothelial bladder cancer. J Immunoassay Immunochem. 2016;37(4):359-67.

17. Nutt JE, Mellon JK, Qureshi K, et al. Matrix metalloproteinase-1 is induced by epidermal growth factor in human bladder tumour cell lines and is detectable in the urine of patients with bladder tumours. $\mathrm{Br} J$ Cancer. 1998;78:215-20.

\section{Ready to submit your research? Choose BMC and benefit from:}

- fast, convenient online submission

- thorough peer review by experienced researchers in your field

- rapid publication on acceptance

- support for research data, including large and complex data types

- gold Open Access which fosters wider collaboration and increased citations

- maximum visibility for your research: over $100 \mathrm{M}$ website views per year

At BMC, research is always in progress.

Learn more biomedcentral.com/submissions 